\title{
FACTORS AFFECTING BIASING OF CAPITAL BUDGETING CASH FLOW FORECASTS: EVIDENCE FROM THE HOTEL INDUSTRY
}

\author{
MICHAEL J. TURNER (corresponding author) \\ University of Queensland \\ UQ Business School \\ St. Lucia Campus \\ QLD 4072 \\ AUSTRALIA \\ Phone: +61 733468071 \\ Fax: +61 733468199 \\ Email: m.turner@business.uq.edu.au
}

and

\author{
CHRIS GUILDING \\ Griffith University \\ Griffith Business School \\ Gold Coast campus \\ QLD 4222 \\ AUSTRALIA \\ Phone: + 61755528790 \\ Fax: +61 755528507 \\ Email: c.guilding@griffith.edu.au
}

\begin{abstract}
Author's note: This paper has benefitted from anonymous referee comments provided in the course of the paper's review process. The authors would also like to acknowledge the helpful suggestions provided by attendees at the AFAANZ Conference Darwin, Australia. Valuable feedback was also received from attendees at seminars hosted by the School of Accounting and Business Information Systems at the Australian National University as well as the School of Accounting, Economics and Finance at Deakin University. Finally, the paper has profited from useful audience comments provided at the University of Queensland Research Forum.
\end{abstract}




\title{
FACTORS AFFECTING BIASING OF CAPITAL BUDGETING CASH FLOW FORECASTS: EVIDENCE FROM THE HOTEL INDUSTRY
}

\begin{abstract}
This study contributes to a neglected aspect of the capital budgeting process, namely, the proposal development stage, which is primarily concerned with project cash flow estimation. Given that the deployment of sophisticated selection techniques is severely undermined when directed to input data suffering from bias, it is surprising that minimal empirical research has sought to explore for antecedent factors associated with biasing of capital budgeting cash flow forecasts. This paper reports the findings of a survey concerned with determining factors associated with biasing of capital budget cash flow forecasts in hotels that are mediated by a management contract. Statistically significant support is provided for the view that higher levels of biasing of capital budget cash flow forecasts occur in the presence of: high emphasis attached to the payback investment appraisal method; deficient reserve funds for furniture, fittings, and equipment (FF\&E); low operator accessibility to reserve funds for FF\&E; shorter periods of time to management contract expiry; and high emphasis attached to non-financial factors in capital budgeting appraisal.
\end{abstract}

Keywords: capital budgeting; cash flow forecasting; FF\&E reserve; hotel management contract; payback; power 


\section{FACTORS AFFECTING BIASING OF CAPITAL BUDGETING CASH FLOW FORECASTS: EVIDENCE FROM THE HOTEL INDUSTRY}

\section{Introduction}

The corporate finance literature sees capital budgeting as comprising four stages: (1) project identification; (2) project development; (3) project selection; and (4) project control (see reviews by Burns and Walker 2009, Gordon and Pinches 1984, Mukherjee and Henderson 1987). This paper reports the findings of a study focussed on biasing of capital budget cash flow forecasts (CBCFFs), which falls within the project development stage.

Biasing of capital budgeting cash flow forecasts has its foundations with asymmetric information, where the agency model is central (Bohlin 1997). The presence of information asymmetry can facilitate agents' biasing of CBCFFs for those projects that will benefit their self-interest relative to projects that may have better fulfilled the goals of the principal (see Haka 2007 for a review).

Given the extensive literature concerning agents' biasing of operational budgets (e.g. Davila and Wouters 2005, Dunk 1993, Lukka 1988, Merchant 1985, Van der Stede 2000), one is struck by the scant attention directed to the potential for biasing cash flow projections in connection with capital budgeting. An extensive literature search has identified only four empirical studies that have expressly examined the issue (see Guilding 2003, Guilding and Lamminmaki 2007, Lazaridis 2006, Pruitt and Gitman 1987). None of these studies, however, sought to develop a framework concerning variables that might affect the extent of biasing of CBCFFs. This appears as surprising on three counts. Firstly, there would appear to be considerable scope for biasing of CBCFFs, as, unlike the context of operational budgeting, managers reviewing capital expenditure proposals generally do not have the benefit of prior years' data to use as a gauge in appraising the accuracy of a forecast. Secondly, it is notable that efforts directed towards deploying increasingly sophisticated project selection techniques will be rendered futile if input data suffers from bias. Thirdly, there has been a large number of studies concerning the control stage of capital budgeting that have uncovered significant deviations between forecasted and realised cash flows. Commenting on this literature, Linder (2005) notes that a large proportion of these deviations derive from optimistic cash flow forecasts and that this issue warrants research enquiry directed towards determining the causes of such biasing. 
The lack of prior attention directed to CBCFF prompted the pursuit of the following objectives in the study reported herein:

(1) to appraise the incidence of biasing of CBCFFs in hotels mediated by a management contract; and

(2) to develop and test hypotheses concerned with factors that might affect the extent of biasing of CBCFFs in hotels mediated by a management contract.

The remainder of the paper is structured as follows. The next section provides a review of pertinent literature and includes a rationale for this study's focus on the hotel industry. After this, hypotheses concerned with factors that might affect biasing of CBCFFs are developed. Subsequent sections address, in turn, the survey research method employed, the study's findings and a conclusion that discusses implications arising.

\section{Literature review}

Four reasons for biasing of CBCFFs have been advanced in the normative literature: technical, economic, psychological, and political (see Flyvbjerg et al. 2002). Technical causes of biasing are sometimes referred to as 'forecasting errors' (Cantarelli et al. 2008, p. 2). Such errors are unintentional and stem from imperfect techniques, inadequate data, honest mistakes, inherent problems in predicting the future, or a lack of forecaster experience (Flyvbjerg et al. 2003). Sub-explanations of these problems can include: poor project design and implementation; incompleteness of estimates; deficient organisation structure; poor decision-making or planning processes; and uncertainty (Cantarelli et al. 2008). Technical error can be minimised through development of better forecasting models, better data, and more experienced forecasters (Flyvbjerg 2007).

Economic causes of biasing of CBCFFs arise where approval of a project can have a positive economic effect, either directly or indirectly, on stakeholders who have a capacity to influence CBCFFs (Flyvbjerg et al. 2002). If involved in the CBCFF process, it would be rational for such stakeholders to inflate projected revenues and deflate projected costs, in order to raise the likelihood of project acceptance (Cantarelli et al. 2008). A lack of an incentive to formulate a CBCFF accurately, combined with ample scope to bias a CBCFF, provides fertile ground for biasing of CBCFFs if the forecaster stands to derive economic benefit from a project proposal securing approval (Cantarelli et al. 2008). 
Psychological causes of biasing of CBCFFs relate to the mental state of the forecaster. Forecasters can hold an innate optimistic predisposition towards the outcomes of a proposed project (Flyvbjerg 2007). The extent to which such psychological biasing is intended appears unclear, however. Overoptimism can be traced to cognitive biases which are essentially errors in the way the human mind processes information (Flyvbjerg et al. 2002, Lavallo and Kahneman 2003). The human psyche is distinguished by a significant ability to learn from experience and such experience would result in the reduction of unintentional biasing of CBCFFs (Flyvbjerg et al. 2002).

Political causes of biasing of CBCFFs relate to a forecaster using the formulation of a $\mathrm{CBCFF}$ as an opportunity to pursue interests related to their career and power base (Flyvbjerg 1998). Overstating the net benefits of a projected capital expenditure in order to gloss over the potential for failure can be rational for a manager concerned with jockeying for hierarchical position in the face of a limited capital expenditure budget (Flyvbjerg 2007). Securing insights into the extent of this phenomenon is bound to be difficult, however, as forecasters would be reluctant to provide information that betrays the extent to which they use the development of $\mathrm{CBCFF}$ as an opportunity to pursue their personal political agenda (Flyvbjerg 1996).

Despite theoretical explanations for biasing of CBCFFs, empirical examination of the phenomenon has been minimal. Consistent with the view of Miller and O'Leary (2007) that the accounting literature concerned with capital budgeting practice has exhibited little development in recent decades, a literature review has identified just four prior empirical studies focused on biasing of CBCFFs. Pruitt and Gitman (1987) surveyed Fortune 500 firms and found that $80 \%$ of high-ranking financial officers perceived profitability forecast error to be compounded by a pronounced upward bias in revenue forecasts and a less-pronounced downward bias in cost forecasts. Two-thirds of the sample believed that biases occurred as a result of intentional overstatement or a lack of experience. The other third felt that bias was psychologically based (e.g. myopic euphoria, mass psychology, group polarisation, or salesman optimism), or the result of erroneous information provided by upper level management. They also observed that managers involved in reviewing CBCFF tend to adjust cash inflow estimates downward to compensate for a projected net cash inflow inflation propensity. 
Guilding (2003) conducted a series of field study interviews within the context of the Australian hotel industry. He found that, consistent with the expectations of agency theory, capital budgeting systems in hotels mediated by a management contract have a greater degree of capital budgeting formalisation and a higher propensity for biasing of CBCFFs than hotels that are not managed under a management contract.

In a study of small and medium sized Mediterranean-based companies, Lazaridis (2006) found detailed cash flow estimates to be required for almost all types of investment and a large proportion of his sample adopted standardised procedures for estimating items such as taxes, depreciation, and salvage values. Of particular note, the majority of Greek firms surveyed were found to adjust CBCFFs in order to compensate for overoptimistic biasing.

Based on Australian survey data, Guilding and Lamminmaki (2007) benchmarked the degree of biasing of CBCFFs in hotels relative to other industries. A significantly greater propensity to inflate project cash inflows relative to deflating projected cash inflows was observed across the whole sample. Contrary to the researchers' expectation, less biasing of CBCFFs was observed in the hotel sector relative to the other industrial sectors examined.

Somewhat surprisingly, no study pursuing an explicit focus on the causes of biasing of $\mathrm{CBCFF}$ has been found. However, some empirical studies concerned with the control phase of capital budgeting provide some useful insights into biasing of CBCFFs. For example, Van Vleck (1976) found that businesses representing the electronics and home appliance, chemical, glass, concrete, metals, mining and textile sectors exhibit the highest deviations between planned and actual cash flows. The pharmaceutical industry produced the smallest deviation. No significant association between CBCFF error and company size or profitability was observed. Merrow et al. (1981) focused on pioneer plant investments in chemical process industries and found that the extent of deviations between actual cash flows and CBCFF could be explained by three context specific factors: plant technology, plant site characteristics and plant complexity. Merrow et al. (1981) also noted a positive relationship between new technology projects and the size of CBCFF deviations. Flyvbjerg et al. (2002) found $\mathrm{CBCFF}$ cost underestimation to be significantly affected by project type. They found that compared to road construction, rail projects have a much greater deviation between 
actual cash flows and CBCFFs. Soares et al. (2007) found no association between business size, industry, region, or investment incentives and $\mathrm{CBCFF}$ error.

As specific facets of an industry can be expected to carry the potential to affect the propensity for biasing of CBCFFs, the study reported on herein was framed in an industry specific manner. We believe that the hotel sector provides a particularly rich context to study biasing of CBCFFs for a number of reasons. Firstly, the hotel industry is characterised by high capital intensity (Collier and Gregory 1995). This underscores the importance of hotel capital budgeting processes (Guilding and Hargreaves 2003). A large US study found hotel capital expenditure equating to $5.4 \%$ of gross revenue (ISHC 2007). Secondly, capital budgeting is rendered more complex in hotels that operate with a management contract. Under a hotel management contract, one party (the owner) owns the hotel and its associated assets and a second party (the operator) manages the hotel's day-to-day operational activities (Rushmore 2002). In this situation, the key agent responsible for developing capital expenditure proposals for consideration by an owner is the general manager, who is an employee of the operator, not the entity owning the hotel (Eyster 1997). Although the owner is the party that stands to gain most from instilling a culture supportive of high quality investment proposal formulation, it is also the contracting party with a muted capacity to affect the organisational culture experienced by that individual who has a particular capability to influence the initiation of a capital expenditure proposal (Guilding 2003, 2006). As management contracts generally remunerate hotel operators using a percentage linked to hotel revenue and profit, there appears to be an incentive for operators to engage in biasing of CBCFFs in a manner consistent with promoting greater owner capital expenditure (see Turner and Guilding 2010b).

\section{Developing hypotheses concerning CBCFF biasing}

\subsection{Locus of power between hotel owner and operator}

The study of organisational power branches into three distinct but overlapping areas: (1) the intra-organisational power literature, which investigates power between individuals within the same organisation (see Brass 2002 for a review); (2) the organisational power literature, which studies the power of groups in connection with their relationship with, or dependency on, an organisation (see Ocasio 2002 for a review); and (3) the interorganisational power literature, which concerns power between organisations (see Mizruchi and Yoo 2002 for a 
review). The main point of difference between these three literatures concerns the unit of analysis. The unit of analysis in the intra-organisational power literature is an individual, the unit of analysis in the organisational power literature is a group of people, and the unit of analysis in the inter-organisational power literature is an organisation.

In all three literatures, power is viewed as 'a change in the belief, attitude, or behavior of [an actor] ... which results from the action or presence of another [actor]' (Raven 1990, p. 495). Within this definition, it is important to note that the 'intentionality' of power needs to be present (Fairholm 1993, pp. 8-9). This concept outlines that the term 'power' should only be used in connection with those actions that are carried out intentionally. To include the unintended outcomes of wielding power would render the term too broad, as it would capture every conceivable action (Krause and Kearney 2006).

A further issue to recognise in a consideration of power is that although the words 'power' (i.e. actual power) and 'influence' (i.e. the ability to wield power) are sometimes used interchangeably (Pfeffer 1992), Krause and Kearney (2006) feel it is important to distinguish between the two terms. Despite this, power researchers tend to define 'power as an ability' (e.g. Fairholm 1993). Such a definition, however, fails to recognise that power is always a reciprocal interaction between an agent (A) and another party (B) (Mintzberg 1983). For example, by not recognising this reciprocal interaction, it would lead to a failure to appreciate that the power of A not only depends on the available resources of A, but also on the demand for those resources by B, as well as the opportunity of B to obtain those desired resources from another party (Thibaut and Kelley 1959). In this way, B plays an active role in their relationship with A (Krause and Kearney 2006). This aspect of power relations is often referred to as the 'relationality' of power relations (Hardy and O'Sullivan 1998, pp. 462-463).

Krause and Kearney (2006) also note that another important concept in power relations is the level of 'dependency' (Hardy and O'Sullivan 1998, p. 462). Emerson (1962, p. 32) explains that:

'... the dependence of actor A upon actor B is (1) directly proportional to A's motivational investment in goals mediated by B, and (2) inversely proportional to the availability of those goals to A outside the A-B relation.' 
Elaborating on this quote, Emerson (1962, p. 32) notes that 'goals' are taken to mean the 'gratifications consciously sought as well as rewards unconsciously obtained through the relationship'. With respect to the 'availability of those goals to A outside of the A-B relation', this refers to the 'alternative avenues of goal-achievement' (Emerson 1962, p. 32). Therefore, the greater is B's dependency on A, the greater will be A's power over B. Where B seeks to pursue alternative avenues of goal-achievement, however, the costs of such an approach must be included in the assessment of dependency (Emerson 1962).

The locus of power between a hotel owner and operator in a relationship mediated by a management contract clearly relates to the inter-organisational power literature referred to above. Several factors have been documented as affecting the relative locus of power between a hotel owner and operator. These include: (1) the level of competition among operators, with more competition leading to lower operator power (Bader \& Lababedi 2007); (2) the relative size of the hotel owner, with larger hotel owners holding more power (Beals and Denton 2005); and (3) the strength of the hotel operator's brand, with stronger brands handing the operator greater power (Armitstead 2004, Forgacs 2003). An earlier study conducted by the research team suggests further that the locus of power between a hotel owner and operator is also influenced by the extent to which the owner's hotel property is in an area highly sought after by hotel operators (e.g. close to a tourism icon), the condition of the property and the extent to which it is located in close proximity to similar competing properties. If a well-appointed hotel property is located close to a tourism icon and there are few competing properties in close proximity, the owner would likely have the capacity to wield considerable power.

It is to be expected that where a hotel owner enjoys significant power in a relationship, the owner will use this power to impose conditions on the way that a hotel operator develops CBCFF in a manner consistent with limiting their scope to introduce bias to CBCFF. Guilding (2003) notes that in this capital budgeting context, it is the operator that tends to initiate capital budgeting proposals. Following the initiation of a proposal, focused deliberations between the owner and operator will ensue, as it is the owner who has to finance any asset purchase (Guilding 2003). Such deliberations will give ample scope for the dynamics of the locus of power between the two parties to play out in the course of the finalisation of the CBCFFs in advance of them being subjected to whatever suite of capital expenditure appraisal techniques are deployed by the owner. In addition to these factors, it 
would appear inconsistent for an operator that has a high dependency on an owner (relative to the owner's dependency on the operator), to potentially jeopardise the smooth running of the relationship by consistently seeking to inject bias into CBCFF. Hypothesis 1 has been formulated in a manner consistent with this rationale:

H1. Higher owner locus of power is associated with less biasing of capital budgeting cash flow forecasts.

\subsection{Emphasis attached to the payback investment appraisal method}

There have been many surveys of capital budgeting techniques (e.g. Gitman and Vandenberg 2000, Graham and Harvey 2001, Ryan and Ryan 2002). Most find payback, net present value (NPV) and the internal rate of return (IRR) to be the most popular capital budgeting appraisal techniques. Payback is considered simple, while NPV and IRR are viewed as more sophisticated due to the discounted cash flow methodology that they entail (Ballantine and Stray 1999).

Haka (2007) notes that there has been a steady increase in the use of sophisticated capital budgeting techniques since the 1950s. Many commercial contexts may not provide enough predictability and certainty for the full benefits of sophisticated techniques to be reaped, however (Mouck 2000). Both techniques require the assignation of subjectively determined risk premiums (most common) or modelling, such as the capital asset pricing model or sensitivity analysis (Shao 1994). This signifies that the application of discounted cash flow techniques provides more than one outlet for introducing biasing of CBCFFs. In the case of NPV analysis, the party seeking to bias the analysis could massage cash flows or modify the risk adjusted discount rate. Similarly, if applying the IRR approach, the party seeking to bias an analysis could massage cash flows or modify the risk adjusted required rate of return. The scope for such behaviour appears broad when one considers that Bierman (1993) found that the capital budgeting discount rate used in $72 \%$ of Fortune 100 industrial firms is based on the risk or the nature of a specific project. In a similar vein, Graham and Harvey (2001) reported that $51 \%$ of their surveyed firms would always, or almost always, use a risk-matched discount rate when appraising capital expenditure proposals. These observations signify that the required rate of return does not tend to be fixed in organisations, rather, it is modified in line with management's somewhat subjective appraisal of a particular project's risk. The significant amount of subjectivity in calculating inputs to sophisticated capital budgeting appraisal techniques can therefore lead to managerial self-serving bias (Tole et al. 1997). 
Marino and Matsusaka (2005) note that such bias represents a source of increased information corruption.

In those situations where a hotel owner applies a risk adjusted discount rate in NPV and IRR analysis, there would appear to be considerable scope for the operator to influence the risk profile assigned to capital expenditure proposals. Partial support for this view derives from Guilding's (2003) observation that it is the hotel operator that acts as the main instigator of hotel capital expenditure projects. ${ }^{1}$ The opportunity to introduce bias appears to be much more constrained when applying the payback technique, however, as it does not require the development of a risk adjusted discount rate or required rate of return. This signifies that all of the biasing intent would need to be channelled into cash flow massaging if high emphasis is placed on the payback method. It is therefore expected that high use of the payback method will result in more biasing of CBCFFs. Hypothesis 2 is worded in a manner consistent with this expectation:

H2. Higher emphasis attached to the payback method in capital budgeting appraisal is associated with more biasing of capital budgeting cash flow forecasts.

\subsection{Adequacy of funds allocated to the $F F \& E$ reserve account}

Turner and Guilding (2010a) provide a detailed examination of the manner in which most hotel management contracts require owners to establish a reserve for the replacement of furniture, fittings and equipment (FF\&E). This account is designed to fund all capitalised hotel asset expenditures other than real estate (Bader and Lababedi 2007). The amount to be allocated to the FF\&E reserve is generally stipulated in the hotel management contract and is moderated by the rolling nature of FF\&E capital expenditure (Rushmore 2002). Owners generally require approval of competitive bids on all FF\&E reserve funded requests from operators as well as the provision of a well formulated capital budgeting proposal for projects of any substance in terms of size (Eyster 1997). A hotel's FF\&E can account for up to 25 per cent of the value of a hotel property (Rushmore and Baum 2001). Determining what constitutes a sufficient allocation to the FF\&E reserve, however, represents a considerable challenge (Mellen et al. 2000).

Allocations to the FF\&E reserve are most commonly based on a predetermined percentage of gross revenue (Turner and Guilding 2010a). Since the 1930s, the general rule of thumb has been that annual contributions to the FF\&E reserve should be set at around three per cent of 
annual gross revenues (Brooke and Denton 2007). This amount, however, is typically insufficient to cover the true cost of FF\&E expenditure because it ignores plant life cycles, routine maintenance costs and hotel building ageing (Reichardt and Lennhoff 2003). This is why some management contracts allow more than the 'rule of thumb' to be contributed to the FF\&E reserve (see Turner and Guilding 2010a). Nevertheless, Turner and Guilding (2010a) found that FF\&E reserves remain, for the most part, significantly underfunded.

The extent to which a hotel's FF\&E reserve is underfunded would appear to be an important contextual factor in hotel capital budgeting, particularly given the relative size of capital expenditure on FF\&E in a typical hotel. Based on the premise that operators will find it more difficult to secure owner funding for capital expenditure once the FF\&E reserve fund has been expended, operators can be expected to perceive a greater need to demonstrate the worthiness of proposed capital expenditures when FF\&E reserves are limited. This incremental need to demonstrate the worth of capital expenditure will be absent in hotels that maintain relatively high adequacy of the FF\&E reserve account. Hypothesis 3 is postulated in a manner consistent with this view.

H3. Lower FF\&E reserve adequacy is associated with more biasing of capital budgeting cash flow forecasts.

\subsection{Challenge in accessing $F F \& E$ reserve account funds}

Operation of the FF\&E reserve account has the potential to be a source of significant tension between hotel owners and operators, particularly in connection with the manner in which funds are released from the reserve (Corgel 2007). Release of funds is generally achieved only following the provision of owner approval (Turner and Guilding 2010a). A lessening of operator access to FF\&E funds can be expected to result in operators perceiving a heightened need to demonstrate the worthiness of capital expenditure proposals. This heightened need for capital expenditure proposals to provide a persuasive case supportive of greater capital expenditure can be facilitated via the preparation of optimistically biased cash flow forecasts. Hypothesis 4 is formulated in a manner consistent with this rationale.

H4. Higher degrees of challenge experienced in accessing FF\&E reserve account funds is associated with more biasing of capital budgeting cash flow forecasts.

\subsection{Remaining length of management contract}


It has long been claimed that long-term contracts can mitigate inconsistent principal/agent interests (see Haka 2007 for a review). As capital budgeting cash flow forecasts can be used by an owner as a basis for monitoring subsequent performance, there is an incentive for an operator to refrain from biasing cash flow forecasts. This incentive will lessen as the maturity date of a management contract approaches, due to the diminution of the period that the forecast can be used as a performance benchmark. ${ }^{2}$ Further, Guilding (2003) suggests that where an operator is in a long-term relationship with an owner, there is a greater likelihood that the operator will seek to instill and maintain trust in the relationship. The submission of biased cash flow forecasts to an owner would appear to be an operator action that is inconsistent with an ethos of engendering trust in a relationship, as it raises the spectre of owner disappointment arising from failure to achieve forecast cash flows. Hypothesis 5 is promulgated in a manner consistent with this rationale.

H5. Shorter periods of time to management contract expiry are associated with more biasing of capital budgeting cash flow forecasts.

\subsection{Emphasis on financial versus non-financial factors in investment appraisal}

To assist in the capital budgeting decision-making process, financial and non-financial capital budgeting appraisal techniques are often used (Moyer et al. 2001). Although there has been a substantial focus within the literature on the use of different financial capital budgeting appraisal techniques such as NPV, IRR and payback (e.g. Graham and Harvey 2001), limited research attention has been given to the relative importance of non-financial factors in investment appraisal (Chen 2008).

There appear to be two reasons suggesting that the relative degree of emphasis attached to financial and non-financial investment appraisal factors might represent a potentially important factor affecting biasing of CBCFFs. If high emphasis is attached to financially oriented investment appraisal approaches, there would appear to be a greater incentive to bias cash flow forecasts, as this data would be carrying a relatively high influence when seeking to determine a proposal's merit. On the other hand, where high emphasis is attached to financially oriented investment appraisal approaches, an owner would likely more closely monitor the propensity for bias in cash flow forecasts and this greater monitoring might lessen the extent of biasing of CBCFFs. This rationale signifies that high emphasis attached to financially oriented investment appraisal approaches could give rise to conflicting effects 
on biasing of CBCFFs. In light of this, hypothesis 6 has been developed in a non-directional manner.

H6. Relative emphasis attached to financial versus non-financial factors in investment appraisal is associated with biasing of capital budgeting cash flow forecasts.

\section{Sampling method}

A mailed questionnaire survey was sent to general managers in Australian and New Zealand hotels with twenty or more rooms and a minimum star-rating of three. This provided a total sample size of 664, comprising 463 Australian hotels and 201 New Zealand hotels. It is only hotels operating with a management contract that evidence four of the factors invoked in the analysis: locus of power between owner and operator; adequacy of funds allocated to the FF\&E reserve account; challenge in accessing FF\&E reserve account funds; and remaining length of management contract. However, no database could be identified that was limited to hotels operating with a management contract only. The questionnaire was therefore sent to all hotels in the sample frame and included a screening question that elicited the operating modal type for each respondent's hotel.

Three weeks subsequent to the initial mailing, a follow-up mailing was sent to the entire sampling frame. Two weeks after the second mailing, a number of hotel owner representatives known to the research team agreed to circulate the questionnaire to general managers with whom they had close contact. This generated a further 51 responses. Two weeks subsequent to the owner representatives' distribution of questionnaires, the sample was contacted by email and encouraged to complete the questionnaire which was provided as an attachment. Finally, two weeks after the email approach, random telephone calls were made to 31 general managers. The objective of these phone calls was threefold: to thank the general manager if they had already completed the survey; to ascertain the main reasons for nonparticipation in the study; and to encourage participation in the study. The survey response pattern is reported in Table 1.

\section{INSERT TABLE 1 ABOUT HERE}

Two investigations for non-response bias were undertaken. Non-response reasons provided by the hotels contacted by phone included 'completing questionnaires contravenes company policy', 'too busy' and 'the general manager was away on holiday'. No factors cited 
suggested the presence of any systematic non-response bias. Secondly, an investigation for profile differences between the first mailing respondents and the remainder of the respondents was undertaken. Although a Mann-Whitney $U$ Test revealed some differences, the statistical strength of association between the two groups ( $r$ value) was small (i.e. $r<.2$ ) (see Cohen 1988). These investigations suggest the issue of non-response bias does not constitute a strong threat to the validity of the study's findings.

\section{Variable measurement}

\subsection{Locus of power between hotel owner and operator}

Given that two distinct organisations are involved in a hotel management contract, the owner and the operator, it appeared appropriate to guide the current study's operationalisation of a power measure by the inter-organisational power literature. Inter-organisational power survey research is usually framed according to two common power perspectives: (1) an assessment of the alternative choices available to both organisations in the negotiation phase; and (2) the strategic importance of the relationship to the organisations at the time of contract negotiation. Difficulties arise when attempting to apply these conceptualisations of power to the context of the current study, however. These relate to the fact that the best placed party to comment on the locus of power between hotel owner and operator is the hotel general manager. There is a low likelihood, however, that a general manager responding to the survey questionnaire would be in a position to comment on the conditions existing at the time that the hotel management contract was negotiated. This is because of general managers' notoriously high job mobility (Akrivos et al. 2007) and also the fact that management contracts are typically entered into for ten or more years (Haast et al. 2005). Despite these concerns, the hotel general manager would appear to be in a very strong position to provide a well-informed perspective on the locus of power between owner and operator. This is because while the operator employs the general manager, the general manager's appointment typically requires approval of the owner, and it is the owner that funds the general manager's salary (Guilding 2003). Guilding (2006, pp. 403-405) comments:

'... the general manager ... can be seen to be well placed to observe any 'cross-fire' between a hotel owner and operator. [general managers are strategically placed] ... with respect to mediating the relationship between hotel owner and operator.' 
Based on the view that a general manager is motivated to maintain a strong working relationship with both the owner and operator, it is argued that for the purposes of gauging power in the current study, a general manager's relationship with both the owner and the operator can be viewed as being similar to a 'within organisation' relationship. This is because a hotel owner and operator are in an enduring organisational relationship. In light of this, the well-established intra-organisational power literature can be drawn upon to inform the development of a measure of the locus of power between hotel owners and operators.

Within the intra-organisational power literature, Krause and Kearney (2006) explain that much empirical questionnaire survey based research has been conducted within a broad range of organisational contexts and that a classical five power base typology developed by French and Raven (1959) has been used. This typology comprises: (1) reward power; (2) coercive power; (3) legitimate power; (4) referent power; and (5) expert knowledge power. French and Raven (1960, pp. 612-613) describe their five bases of power in which an agent, O, can exert influence over a person, $\mathrm{P}$, as follows:

'(a) Reward power, based on P's perception that $\mathrm{O}$ has the ability to mediate rewards for him; (b) coercive power, based on P's perception that $\mathrm{O}$ has the ability to mediate punishments for him; (c) legitimate power, based on the perception by $\mathrm{P}$ that $\mathrm{O}$ has a legitimate right to prescribe behaviour for him; (d) referent power, based on P's identification with $\mathrm{O}$; (e) expert power, based on the perception that $\mathrm{O}$ has some special knowledge or expertise.'

Within the current study, it was determined that the locus of power between hotel owner and operator could be most effectively elucidated by determining which of the two contracting parties exerted the greatest influence over the general manager. Following a review of the intra-organisational power literature, Krause and Kearney (2006) recommend that: (1) power bases be measured through the use of multi-item measurement; (2) that responses be rated rather than ranked; and (3) that future studies measure the wielding of power in its dependency on the particularities of the situation (i.e. context specific). Krause and Kearney's (2006) recommendations were heeded in developing the current study's power measure. This has resulted in three separate context specific questions being posed for each of French and Raven's (1959) five power bases, using a seven-point Likert-type scale. The 15 items are preceded by the introductory wording: 'In terms of your hotel owner and your hotel operating company, which entity is in a stronger position to:'. Column four of Table 2 presents the 15 
items posed together with an identifying code for each item. The Table's first three columns capture the origin of each item and the Table's final three columns in respective order provide each item's mean, standard deviation and number of observations in the sample.

\section{INSERT TABLE 2 ABOUT HERE}

In addition to these fifteen items, one question was posed as a holistic measure of the locus of power between hotel owner and operator. Respondents were asked: 'In terms of influencing the hotel's objectives/goals, which is more powerful?' A Likert scale was provided that ranged from ' 1 ' (the operator) to ' 7 ' (the owner). This question generated a mean of 3.21 and a standard deviation of $1.53(n=100)$.

An assessment of the suitability of applying factor analysis to the data collected via the 15 items was undertaken, consistent with the view that power is a multidimensional variable (French and Raven 1960). An independent factor analysis was conducted for each of the three sets of items comprising the five dimensions of power. In all cases, correlations between the three items were highly statistically significant $(p<.01)$. Kaiser Meyer Olkin and Bartlett's Test indicated favourable sampling adequacy. Communalities were greater than the recommended 0.5 threshold in all but one case (item L1 at .382). Hair et al. (2006) indicate that items yielding communalities below 0.5 can be ignored. As the L1 item derives from a measure that has been used in prior studies, it was deemed preferable to retain the item within the factor solution. For each of the five dimensions of power, a single factor solution with an Eigenvalue greater than 1 was extracted, with a variance explained greater than the $60 \%$ recommended threshold (Hair et al. 2006). All item loadings were above the recommended .55 threshold and were statistically significant $(p<.05)$. These findings support the measurement of the five dimensions of power by calculating the mean of the three underlying items for each of the five item groupings.

The degree of association between the five dimensions of power and also the holistic measure of power was examined using correlation analysis (see Table 3). This table shows that all items are highly statistically significantly correlated at $p<.01$. The strong correlation between the holistic item and all five dimensions of power constitutes a strong affirmation as to the reliability of the holistic measure. In light of this, the holistic item has been employed as the measure of power in hypothesis testing. 


\section{INSERT TABLE 3 ABOUT HERE}

\subsection{Emphasis attached to the payback investment appraisal method}

Rather than using an absolute measure of payback usage, it was felt that a more refined payback emphasis indicator would result if the use of payback were gauged relative to the use of other popular investment appraisal techniques. Following the question 'To what extent are the following capital budgeting investment appraisal techniques used in your hotel?', the NPV, IRR and Payback techniques were listed. For each of these techniques, the respondent recorded a score on a Likert scale that ranged from ' 1 ' ('not at all') to '7' ('to a large extent'). Table 4 provides the mean and standard deviation statistics for these three items.

\section{INSERT TABLE 4 ABOUT HERE}

Emphasis attached to the payback investment appraisal method has been measured by taking a respondents' score for the highest ranking item out of NPV or IRR and subtracting it from their score for the payback item (i.e. Payback - higher of NPV or IRR). This measure generated a mean of .76 and a standard deviation of $1.71(n=101)$. The rationale for using only the score for the most dominant item of NPV or IRR stems from the view that the highest scoring item represents the most appropriate benchmark to use when seeking to gauge the relative emphasis attached to the payback investment appraisal method.

\subsection{Adequacy of funds allocated to the $F F \& E$ reserve account}

Two approaches were taken to measure the adequacy of funds allocated to the FF\&E reserve account. Firstly, respondents were asked 'To what extent do you consider the funds allocated to the FF\&E reserve in your hotel are sufficient to fund FF\&E expenditure?' Responses were recorded on a Likert scale ranging from ' 1 ' ('not sufficient') to '7' ('very sufficient'). This measure yielded a mean of 3.81 and a standard deviation of $1.55(n=88)$. For the second measure, the respondents were asked the following two questions: (1) 'What percentage of gross revenue is allocated annually to the FF\&E reserve account in your hotel? $\%$; and (2) 'What percentage of gross revenue would be required to cover the true cost of reasonable annual FF\&E expenditure in your hotel? $\%$ '. An index was then computed by taking a subject's score for the first question (actual allocation to the FF\&E reserve) and deducting their score on the second question (true cost of FF\&E reserve). This second measure yielded 
a mean of $-2.14 \%$ and a standard deviation of $1.74(n=70)$. The two measures were highly significantly correlated $(p<.01)$ suggesting high measurement reliability. In the hypothesis testing below, the first of the two measures has been used as the gauge of the adequacy of funds allocated to the FF\&E reserve account. ${ }^{3}$

\subsection{Challenge in accessing $F F \& E$ reserve account funds}

Three items were employed to measure the extent of challenge associated with accessing FF\&E reserve account funds. The first question asked respondents to indicate their affirmation with the statement: 'In my hotel it can be hard to get the owner to release funds from the FF\&E reserve' on a Likert scale ranging from ' 1 ' ('strongly disagree') to '7' ('strongly agree') (mean 3.33, std. dev. 1.85). The second question asked: 'How often does your hotel owner refuse to release funds from the FF\&E reserve?', with responses provided on a Likert scale ranging from ' 1 ' ('never') to ' 7 ' ('frequently') (mean 2.72, std. dev. 1.51). The final question asked 'How much do you have to pressurise your hotel owner in order to get funds released from the FF\&E reserve?' with responses recorded on a Likert scale ranging from ' 1 ' (not at all) to ' 7 ' (very much) (mean 3.17, std. dev.1.83). A correlation analysis revealed statistically significant positive associations between all three items $(p<$ .01). A factor analysis revealed all items having a communality greater than .8 with a single factor solution explaining $83.02 \%$ of the variance. In light of this, the challenge in accessing FF\&E reserve account funds has been measured by calculating the mean of the three items. The three items yielded a strong Cronbach Alpha of .895. The factor developed had a mean of 3.07 with a standard deviation of $1.58(n=88)$.

\subsection{Remaining length of management contract}

No study employing a measure of remaining length of management contract was found in the literature. Given the relatively simple nature of the information sought, respondents were asked 'Approximately how long is it until your management contract expires? (please specify) __ year(s)'. The mean was 8.53 years with a standard deviation of 5.63 years $(n=$ $85)$.

\subsection{Emphasis on financial versus non-financial factors in investment appraisal}

Butler et al. (1993) see three distinct orientations in non-financial approaches to investment appraisal: (1) strategically-oriented investment appraisal, which is evident when high importance is attached to a project's capacity to deliver competitive advantage (Lefley 2004); 
(2) politically-oriented investment appraisal, which is evident when an organisation has highly self-interested individuals who employ guile and strategies such as coalition building to enhance the likelihood of their preferred project proposal being sanctioned by senior management (Hickson et al. 1986), and (3) intuition-based investment appraisal, which is evident when high importance is attached to the exercise of senior management's intuition and judgment (Chami and Fullenkamp 2002). Drawing on this categorisation, three questions were developed relating to each of these non-financial investment appraisal orientations. In addition, three questions were developed to gauge the extent to which financial considerations influence whether a capital expenditure proposal is supported. Table 5 provides an overview of the 12 items developed. The first column identifies the categorisation in Butler et al. (1993). The second column documents the 12 items developed together with an identifying code for each question. The final column provides the mean and standard deviation for each item. For each item, a Likert scale was used ranging from ' 1 ' (not at all) to ' 7 ' (to a large extent). The 12 items were preceded by the wording: 'In your hotel, to what extent do the following factors influence whether an investment proposal is given the go ahead?'

\section{INSERT TABLE 5 ABOUT HERE}

A factor analysis was undertaken, justified on the grounds of the four thematic origins of the 12 questions.. Kaiser Meyer Olkin and Bartlett's Test indicated favourable sampling adequacy. The factor analysis generated three factors with eigenvalues greater than $1(3.830$, 2.608 and 1.128). The relative association of the items with these three factors is evident from Table 6, which presents output from a principal component analysis. The thematic origin of each of the items is provided in the table's second column. While this initially suggested a three factor result, inspection of the eigenvalue scree plot revealed a significant kink in the curve occurring at the locus of the third highest eigenvalue (the fourth and fifth highest eigenvalues were .888 and .798 , respectively). Accordingly, and consistent with Hair et al's (2006) recommendations, it appeared most appropriate to consider two strong underlying factors: ${ }^{4}$

1. Non-financial emphasis (items I2, P2, P3, P1, I1, I3); and

2. Financial emphasis (items F2, F3, F1). 
The three items associated with financial emphasis (the second factor in Table 6) were consolidated by computing their mean, which was 6.04 with a standard deviation of $.78(n=$ 101). These three variables yielded a Cronbach Alpha of .726. The six items associated with non-financial emphasis (the first factor in Table 6) were consolidated by computing their mean, which was 3.85 with a standard deviation of $1.23(n=99)$. These six items yielded a Cronbach Alpha of .850. The measure for emphasis on financial versus non-financial factors in investment appraisal has been calculated by deducting the non-financial investment appraisal emphasis indicator from the financial emphasis indicator. The resultant measure produced a mean of 2.18 with a standard deviation of $1.44(n=99)$.

\subsection{Extent of biasing of capital budgeting cash flow forecasts}

Two prior questionnaire survey based studies (see Guilding and Lamminmaki 2007, Pruitt and Gitman 1987) have sought to measure the extent of biasing of CBCFFs. Drawing on this prior research, Table 7 provides an overview of the items used to measure this dependent variable. Column one shows the source of the original item drawn from prior literature, the second column displays the current study's adapted item and the final three columns show the mean, standard deviation and number of observations in the sample respectively. A seven point Likert scale was used for all three items in the current study, with ' 1 ' corresponding to 'strongly disagree' and '7' corresponding to 'strongly agree'.

\section{INSERT TABLE 7 ABOUT HERE}

The three items were found to be statistically significantly correlated $(p<.01)$. Communalities were computed and item loadings were found to be well above the recommended .50 threshold (Hair et al. 2006) and statistically significant for the first two items listed in Table 7, but not for the third item (.497). As the communality for this third item was close to the recommended .5 threshold, the decision was made to retain the item in the factor analysis. A factor analysis was undertaken yielding one factor with an eigenvalue exceeding 1 ( $71 \%$ variance explained). The factor loadings were found to be well above the recommended .55 threshold $(p<.05)$ for a sample size of 100. In light of this, it was determined that the extent of biasing of CBCFFs would be calculated as the mean of the three items. These three items yield a strong Cronbach Alpha of .784. ${ }^{5}$ 


\section{Results}

Table 8 presents a frequency distribution and the mean scores for the three items 'extent of biasing of capital budgeting cash flow forecasts'. The means ranged from 2.63 to 2.87 . The fact that the mean scores for all three items were below the mid-point (4) of the measurement scale signified that the extent of biasing of capital budgeting cash flow forecasts may be relatively muted. This observation should be qualified, however. The frequency distribution reveals that the proportion of the sample scoring at the mid-point or above is $24 \%$ for the first measure, $21.8 \%$ for the second measure, and $30.8 \%$ on the third measure. This underscores a view that there is considerable variation in the degree to which hotels are biasing CBCFF. It also signifies that approximately one-quarter of the sample are engaging in significant degrees of CBCFF biasing.

\section{INSERT TABLE 8 ABOUT HERE}

To test the study's six hypotheses, the following multiple regression equation was applied: $Y=\beta_{0}+\beta_{1}$ POWER_LOCUS $+\beta_{2}$ EMPHASIS_PAYBACK $+\beta_{3}$ ADEQUACY_FF\&E + $\beta_{4}$ CHALLENGE_FF\&E_RELEASE $\quad+\quad \beta_{5}$ CONTRACT_LENGTH $\quad+$ $\beta_{6}$ FINANCIAL_EMPHASIS $+e$

where:

$Y=$ Extent of biasing of capital budgeting cash flow forecasts.

POWER_LOCUS = Locus of power between hotel owner and operator (hypothesis 1).

EMPHASIS_PAYBACK = Emphasis attached to the payback investment appraisal method (hypothesis 2).

ADEQUACY_FF\&E = Adequacy of funds allocated to the FF\&E reserve account (hypothesis 3).

CHALLENGE_FF\&E_RELEASE $=$ Challenge in accessing FF\&E reserve account funds (hypothesis 4).

CONTRACT_LENGTH = Remaining length of management contract (hypothesis 5).

FINANCIAL_EMPHASIS = Emphasis on financial versus non-financial factors in investment appraisal (hypothesis 6).

Table 9 provides a correlation matrix of all variables in the regression equation. All independent variables are statistically significantly correlated with the dependent variable ( $p$ $<.05)$. None of the independent variables exhibit statistically significant association with one 
another $(p>.05)$. All variable inflation factors in the model (see Table 10) are also well below the suggested threshold of 5 (Kutner et al. 2004).

\section{INSERT TABLES 9 AND 10 ABOUT HERE}

Table 10 presents the results of the multiple regression analysis. The adjusted $R^{2}$ reveals that $32.2 \%$ of the dependent variable's variation is explained by the independent variables. The model is statistically significant $(F=6.614, p<.000, d f=6,65){ }^{6}$

Hypothesis 1 posited that high owner locus of power is associated with less biasing of capital budgeting cash flow forecasts. No support was found for this hypothesis $(p=.150$; onetailed). ${ }^{7}$

Hypothesis 2 posited that higher emphasis attached to the payback method in capital budgeting appraisal is associated with more biasing of capital budgeting cash flow forecasts. Support was found for this hypothesis at the $p<.01$ level of confidence $(p=.008$; onetailed).

Hypothesis 3 posited that low FF\&E reserve account adequacy is associated with more biasing of capital budgeting cash flow forecasts. Support was found for this hypothesis at the $p<.05$ level of confidence $(p=.011$; one-tailed $)$.

Hypothesis 4 posited that higher degrees of challenge experienced in accessing FF\&E reserve account funds is associated with more biasing of capital budgeting cash flow forecasts. Support was found for this hypothesis at the $p<.05$ level of confidence ( $p=.026$; onetailed).

Hypothesis 5 posited that shorter periods of time to management contract expiry are associated with more biasing of capital budgeting cash flow forecasts. Support was found for this hypothesis at the $p<.05$ level of confidence ( $p=.043$; one-tailed).

Hypothesis 6 posited that relative emphasis attached to financial versus non-financial factors in investment appraisal is associated with biasing of capital budgeting cash flow forecasts. This hypothesis was framed in a non-directional manner as arguments could be made for 
either a positive or negative relationship. Support was found for a negative relationship at the $p<.01$ level of confidence $(p=.000 ;$ two-tailed $)$.

\section{Discussion and conclusion}

With respect to examining the incidence of biasing of CBCFFs, while at a general level of abstraction it appears biasing of CBCFFs in hotels mediated by a management contract is not high, considerable variability is in evidence and around $25 \%$ of the sample were found to be engaging in significant degrees of CBCFF biasing. The significance of this observation for hotel owners becomes apparent when the size of the cash flows associated with the capital budget as well as the long term implications arising from capital expenditure committal are recognised. It is notable that the recent past has seen an increase in hotel owners engaging the services of 'asset managers' whose job entails ensuring that the hotel operator is taking actions that are consistent with the hotel owner's interests (Armitstead 2004). It appears reasonable to expect that the increased engagement of hotel asset managers has been instigated by the desire of hotel owners to lessen hotel operator dysfunctional behaviour such as the biasing of CBCFF. This development may well signify that, compared to other sectors, the hotel sector now has relatively low levels of biasing of CBCFFs. Recognition that industry specific factors will likely affect biasing of CBCFFs underscores the need for the research initiative reported herein to be replicated in other industrial contexts.

Hypothesis 1 posited that high owner power is associated with less biasing of CBCFFs. No support was found for this hypothesis ( $p=.150$; one-tailed). It is notable, however, that a statistically significant association $(p<.05)$ was found between high owner locus of power and biasing of CBCFFs (see Table 9). This observed relationship is directionally consistent with hypothesis 1 . While care should be taken not to overstate any inferred relationship between locus of power between hotel owner and operator and biasing of CBCFFs (given failure to find support for hypothesis 1 in the multiple regression analysis), it appears reasonable to suggest that power between a principal and agent could constitute a useful variable to examine in further research, particularly in light of the fact that no prior surveybased empirical accounting study that invokes the power construct has been found in the literature. The power measure developed in this study would appear to be especially useful in any subsequent empirical research that seeks to determine the locus of power between hotel owners and operators and may also provide a platform upon which to build further context specific power measures between principals and agents. 
Support was provided for hypothesis 2 that higher use of the payback method in capital budgeting appraisal is associated with more biasing of CBCFFs. Normative commentaries that outline the relative merits of different investment appraisal methods will need to consider whether they should be broadened to include the view that a downside of the payback method is that it can promote greater biasing of CBCFFs. Consistent with all new research findings, our confidence over the sustained existence of this observed relationship can only be attained through research replication and examination of the relationship in other commercial contexts.

Support was found for hypothesis 3 that lower adequacy of FF\&E reserve is associated with more biasing of CBCFFs. Support was also provided for hypothesis 4 which postulated that higher degrees of challenge experienced in accessing FF\&E reserve account funds is associated with more biasing of CBCFFs. The novelty of these findings derive from the fact that there has been no prior empirical examination of implications arising from hotel FF\&E reserve account management practices. Considered together, these two findings carry a resonance with prior studies that report a heightened potential for biasing in capital budgeting contexts characterised by tight capital rationing regimes (see e.g. Mukherjee and Hingorani 1999). These findings can also be seen to provide an extension to Turner and Guilding's (2010a) examination of FF\&E reserve accounting practice.

Support was also provided for hypothesis 5 that shorter periods of time to management contract expiry are associated with more biasing of CBCFFs. With respect to agency theory grounded perspectives on contracting, this finding provides support for the view that longerterm contracts carry the benefit of promoting greater principal-agent goal congruency (see Haka 2007). The finding also signifies that the interest of principals may be served by expending greater resources monitoring agents in the latter stages of a contract, relative to the early stages of a contract. The extent to which such increased monitoring is justified would, however, be dependent on the resultant benefits relative to higher monitoring costs incurred. This finding suggests that 'stage in a contract's life' could be a useful contextual factor to consider in future capital budgeting research.

Finally, support was provided for hypothesis 6 which posited that relative emphasis attached to financial versus non-financial factors in investment appraisal is associated with biasing of 
CBCFFs. Evidence suggesting a negative relationship between relative emphasis attached to financial factors in investment appraisal and biasing of CBCFFs was found. This observation is particularly notable given the minimal prior accounting research interest in the relativity of financial versus non-financial investment appraisal method applications. This lack of interest appears as surprising as custodians of the capital expenditure budget in all organisations need to calibrate the degree of importance that they will attach to financial relative to non-financial investment appraisal techniques. The significance that has been found for this variable in the current study may well spur further enquiry into the relative importance attached to financial versus non-financial investment appraisal methods, particularly as it can be seen as constituting an 'accounting' variable. At the very least, a greater focus on this variable will shed light on an under-appreciated aspect of the way capital budgeting systems are operationalised in organisations.

This study's focus on biasing of CBCFFs has highlighted a variable that would appear worthy of greater attention from academics and practitioners alike. The degree of research endeavour that has been invested in examining biasing of CBCFFs is meagre relative to the large quantum of research enquiry directed to appraising the relative incidence of different capital budgeting appraisal techniques.

A distinguishing facet of this study has been its focus on a particular industry, the hotel industry. Four of the six variables investigated in this study could not have been examined had a generic, cross-industry, survey approach been taken. The locus of power between owner and operator, adequacy of funds allocated to the FF\&E reserve account, challenge in accessing FF\&E reserve account funds, and remaining length of management contract are factors particular to hotels mediated by a management contract. It is particularly telling that three of these four variables have been found to have a significant effect on the extent of biasing of CBCFFs. This lends support to the view that significant insights can derive from conducting management accounting surveys that focus on particular issues and facets that are specific to a particular industrial sector.

The study's singular industry focus has drawn out another interesting facet of hotel capital budgeting. As a hotel operator is remunerated based on revenue and profitability, there appears little financial incentive for the operator to focus on NPV, IRR or payback when promoting capital expenditure proposals, rather, their remuneration basis suggests they will 
simply be interested in projects that maximise absolute sales and profit levels. As capital is effectively free for operators that have a revenue and profitability linked remuneration basis, one might expect that greater biasing of CBCFFs will occur in the presence of such a remuneration basis.

This study suffers from all the limitations generally associated with social scientific research that is based on mailed questionnaire survey data. In particular, when interpreting the study's results, it should be born in mind that some of the variable measures used had to be developed due to negligible prior attention directed toward the constructs of interest. This signifies that some of the measures do not carry the benefit of extensive prior validation. Although there is no strong reason to suggest that the measures have failed to adequately measure the intended constructs, the possibility of this occurring should be acknowledged. In light of the study's relative novelty, further research directed towards replicating aspects of the work contained within should be welcomed.

\section{References}

Akrivos, C., Ladkin, A., and Reklitis, P. (2007). Hotel managers' career strategies for success. International Journal of Contemporary Hospitality Management, 19(2), 107-119.

Armitstead, M. (2004). Hotel management and operations options: Intellectual capital versus financial capital. Journal of Retail \& Leisure Property, 3(4), 299-307.

Bachman, J. G., Smith, C. W., and Slesinger, J. A. (1966). Control, performance, and satisfaction: An analysis of structural and individual effects. Journal of Personality and Social Psychology, 4(2), 127-136.

Bader, E. E., and Lababedi, A. (2007). Hotel management contracts in Europe. Journal of Retail \& Leisure Property, 6(2), 171-179.

Ballantine, J. A., and Stray, S. (1999). Information systems and other capital investments: Evaluation practices compared. Logistics Information Management, 12(1/2), 78-93.

Beals, P., and Denton, G. A. (2005). The current balance of power in North American hotel management contracts. Journal of Retail \& Leisure Property, 4(2), 129-146.

Bierman, H. (1993). Capital budgeting in 1992: A survey. Financial Management, 22(24).

Bohlin, E. (1997). A survey of managerial incentives and investment bias - common structure but differing assumptions. Journal of Business Finance and Accounting, 24(2), 197248.

Brass, D. J. (2002). Intraorganizational power and dependence. In J. Baum (Ed.), Companion to organizations (pp. 138-157). Malden, MA: Blackwell Business.

Brooke, J., and Denton, G. A. (2007). CapEx 2007: A study of capital expenditures in the hotel industry (pp. 1-98). Alexandria, VA: International Society of Hospitality Consultants.

Burns, R. M., and Walker, J. (2009). Capital budgeting surveys: The future is now. Journal of Applied Finance, 19(1/2), 78-90.

Butler, R., Davis, L., Pike, R., and Sharp, J. (1993). Strategic investment decisions: Theory, practice, and process. London: Routledge. 
Cantarelli, C. C., Flyvbjerg, B., van Wee, B., and Molin, E. (2008). Cost overruns in largescale transportation infrastructure projects: Which explanations can be given? Infrastructure Systems, (Nov), 1-6.

Chami, R., and Fullenkamp, C. (2002). Trust and efficiency. Journal of Banking and Finance, 26(9), 1697-1933.

Chen, S. (2008). DCF techniques and nonfinancial measures in capital budgeting: A contingency approach analysis. Behavioral Research in Accounting, 20(1), 13-29.

Cohen, J. (1988). Statistical power analysis for the behavioral sciences (2nd ed.). Hillsdale, NJ: Lawrence Erlbaum Associates.

Collier, P., and Gregory, A. (1995). Investment appraisal in service industries: A field study analysis of the U.K. hotels sector. Management Accounting Research, 6(1), 33-57.

Corgel, J. (2007). Technological change as reflected in hotel property prices. The Journal of Real Estate Finance and Economics, 34(2), 257-279.

Davila, T., and Wouters, M. (2005). Managing budget emphasis through the explicit design of conditional budgetary slack. Accounting, Organizations and Society, 30(7-8), 587608.

Dunk, A. (1993). The effect of budget emphasis and information asymmetry on the relation between budgetary participation and slack. Accounting Review, 68(2), 400-410.

Emerson, R. A. (1962). Power-dependence relations. American Sociological Review, 27(1), 31-40.

Eyster, J. J. (1997). Hotel management contracts in the U.S.: Twelve areas of concern. Cornell Hotel and Restaurant Administration Quarterly, 38(3), 21-34.

Fairholm, G. W. (1993). Organizational power politics: Tactics in organizational leadership. Westport \& London: Praeger.

Fleisher, C. (2007). Business and competitive analysis methods: Effective application of new and classic methods. New Jersey: Financial Times-Pearson.

Flyvbjerg, B. (1996). The dark side of planning: Rationality and Realrationalitat. In S. Mandelbaum, L. Mazza and R. Burchell (Eds.), Explorations in planning theory (pp. 383-394). New Brunswick, NJ: Center for Urban Policy Research.

Flyvbjerg, B. (1998). Rationality and power: Democracy in practice. Chicago: University of Chicago Press.

Flyvbjerg, B. (2007). Truth and lies about megaprojects. Dames en heren: Collegae hoogleraren en leden van de universitaire gemeenschapo. Document Number)

Flyvbjerg, B., Bruzelius, N., and Rothengatter, W. (2003). Megaprojects and risk: An anatomy of ambition. Cambridge, UK: Cambridge University Press.

Flyvbjerg, B., Holm, M. S., and Buhl, S. (2002). Underestimating costs in public works projects: Error or lie? Journal of the American Planning Association, 68(3), 279-295.

Forgacs, G. (2003). Brand asset equilibrium in hotel management. International Journal of Contemporary Hospitality Management, 15(6), 340.

French, J., and Raven, B. (1959). The bases of social power. Ann Arbor: Institute for Social Resarch.

French, J., and Raven, B. (1960). The bases of social power. In D. Cartwright and A. Zander (Eds.), Group dynamics: Research and theory (2nd ed., pp. 607-623). Evanston, Ill: Row, Peterson.

Gitman, L., and Vandenberg, P. A. (2000). Cost of capital techniques used by major US firms: 1997 vs. 1980. Financial Practice and Education, 10(2), 53-68.

Gordon, L. A., and Pinches, G. (1984). Improving capital budgeting: A decision support system approach. Reading, Mass.: Addison-Wesley.

Graham, J., and Harvey, C. (2001). The theory and practice of corporate finance: Evidence from the field. Journal of Financial Economics, 60(2, 3), 187-243. 
Guilding, C. (2003). Hotel owner/operator structures: Implications for capital budgeting process. Management Accounting Research, 14(3), 179-199.

Guilding, C. (2006). Investment appraisal issues arising in hotels governed by a management contract. In P. J. Harris and M. Mongiello (Eds.), Accounting and financial management: Developments in the international hospitality industry (pp. 400 - 422). Oxford: Butterworth-Heinemann.

Guilding, C., and Hargreaves, B. (2003). How hoteliers do their capital budgeting. Hospitality Review, 5(1), 45-49.

Guilding, C., and Lamminmaki, D. (2007). Benchmarking hotel capital budgeting practices to practices applied in non-hotel companies. Journal of Hospitality and Tourism Research, 31(4), 486-503.

Haast, A., Dickson, G., and Braham, D. (2005). Global hotel management agreement trends [Electronic Version], June, 1-24. Retrieved 15 Sept 2009, from https://classshares.student.usp.ac.fj/TS108/12009/Course\%20Weekly\%20Readings/W k\%202\%20Global\%20hotel\%20management\%20agreement\%20trends.pdf

Hair, J. F., Anderson, R. E., Tatham, R. L., and Black, W. C. (2006). Multivariate data analysis (6th ed.). Englewood Cliffs, New Jersey: Prentice Hall.

Haka, S. F. (2007). A review of the literature on capital budgeting and investment appraisal: Past, present, and future musings. In C. Chapman, A. G. Hopwood and M. D. Shields (Eds.), Handbook of management accounting research (Vol. 2, pp. 697-728). New York: Elsevier.

Hardy, C., and O'Sullivan, L. (1998). The power behind empowerment: Implications for research and practice. Human Relations, 51(4), 451-483.

Hickson, D. J., Butler, R., Cray, D., Mallory, G. R., and Wilson, D. C. (1986). Top decisions: Strategic decision-making in organizations. Oxford: Blackwell.

Hinkin, T. R., and Schriesheim, C. A. (1989). Development and application of new scales to measure the French and Raven (1959) bases of social power. Journal of Applied Psychology, 74(4), 561-567.

ISHC. (2007). CapEx 2007: A study of capital expenditures in the hotel industry (pp. 1-98). Alexandria, VA: International Society of Hospitality Consultants.

Krause, D. E., and Kearney, E. (2006). The use of power bases in different contexts. In C. A. Schriesheim and L. L. Neider (Eds.), Power and influence in organizations: New empirical and theoretical perspective. Greenwich, Conn: Information Age Publishing.

Kutner, M. H., Nachtsheim, C. J., and Neter, J. (2004). Applied linear regression models (4th ed.). New York: McGraw-Hill/Irwin.

Lavallo, D., and Kahneman, D. (2003). Delusions of success: How optimism undermines executives' decisions. Harvard Business Review(July), 56-63.

Lazaridis, I. T. (2006). Cash flow estimation practices in Mediterranean countries. Managerial Finance, 32(8), 625-633.

Lefley, F. (2004). An assessment of various approaches for evaluating project strategic benefits: Recommending the strategic index. Management Decision, 42(7/8), 850862.

Linder, S. (2005). Fifty years of research on accuracy of capital expenditure project estimates: A review of the findings and their validity. Vallendar, Germany: Otto Beisheim Graduate School of Management.

Lukka, K. (1988). Budgetary biasing in organizations: Theoretical framework and empirical evidence. Accounting Organizations and Society, 13(3), 281-301.

Marino, A. M., and Matsusaka, J. G. (2005). Decision processes, agency problems, and information: An economic analysis of capital budgeting procedures. The Review of Financial Studies, 18(1), 301-326. 
Mellen, S., Nylen, K., and Pastorino, R. (2000). CapEx 2000: A study of capital expenditures in the U.S. hotel industry (pp. 1-150). Alexandria, VA: International Society of Hospitality Consultants.

Merchant, K. (1985). Budgeting and the propensity to create slack. Accounting Organizations and Society, 10(2), 201-210.

Merrow, E. W., Phillips, K. E., and Myers, C. W. (1981). Understanding cost growth and performance shortfalls in pioneer process plants. Santa Monica, CA: Rand Corp.

Miller, P., and O'Leary, T. (2007). Mediating instruments and making markets: Capital budgeting, science and the economy. Accounting, Organizations and Society, 32(7-8), 701-734.

Mintzberg, H. D. (1983). Power in and around organizations. Englewood Cliffs, NJ: Prentice Hall.

Mizruchi, M. S., and Yoo, M. (2002). Interorganizational power and dependence. In J. Baum (Ed.), Companion to organizations. Padstow, GB: Blackwell Business.

Mouck, T. (2000). Beyond panglossian theory: Strategic capital investing in a complex adaptive world. Accounting, Organizations and Society, 25, 261-283.

Moyer, R. C., McGuingan, J. R., and Kretlow, W. J. (2001). Contemporary financial management. Cincinnati, Ohio: South-Western.

Mukherjee, T. K., and Henderson, G. V. (1987). The capital budgeting process: Theory and practice. Interfaces, 17(2), 78-90.

Mukherjee, T. K., and Hingorani, V. L. (1999). Capital-rationing decisions of fortune 500 firms: A survey. Financial Practice and Education, 9(1), 7-15.

Ocasio, W. (2002). Organizational power and dependence. In J. Baum (Ed.), Companion to organizations (pp. 363-385). Malden, MA: Blackwell Business.

Pfeffer, J. (1992). Power-management. Wien, Austria: Wirtschaftsverlag Ueberreuter.

Pruitt, S. W., and Gitman, L. (1987). Capital budgeting forecast biases: Evidence from the Fortune 500. Financial Management, 16(1), 46-51.

Raven, B. (1990). Political applications of the psychology of interpersonal influence and social power. Political Psychology, 11(3), 493-520.

Reichardt, H. J., and Lennhoff, D. C. (2003). Hotel asset allocation: Separating the tangible personality. Assessment Journal, 10(1), 25-32.

Rushmore, S. (2002). Hotel investments handbook. Retrieved 25 Sept, from http://www.hospitalitynet.org/news/4021216.search?query=chapter+20+hotel+manag ement+contracts+pdf

Rushmore, S., and Baum, E. (2001). Hotels and motels-valuations and market studies. Chicago: Appraisal Institute.

Ryan, P. A., and Ryan, G. P. (2002). Capital budgeting practices of the Fortune 1000: How have things changed? Journal of Business and Management, 8(4), 355-364.

Shao, L. P. (1994). Capital investment evaluation procedures utilized by North and Latin American affiliates. Multinational Business Review(Spring), 15-21.

Soares, J. O., Coutinho, M. C., and Martins, C. V. (2007). Forecasting errors in capital budgeting: A multi-firm post-audit study. The Engineering Economist, 52(1), 21-39.

Thibaut, J. W., and Kelley, H. H. (1959). The social psychology of groups. New York: Wiley.

Tole, T. M., Hand, J., and McCord, S. O. (1997). The multinational firms' bias for risky capital projects. Multinational Business Review, 5(2), 10-16.

Turner, M. J., and Guilding, C. (2010a). Accounting for the furniture, fittings and equipment reserve in hotels. Accounting and Finance, 50(4), 967-992.

Turner, M. J., and Guilding, C. (2010b). Hotel management contracts and deficiencies in owner-operator capital expenditure goal congruency. Journal of Hospitality and Tourism Research, 34(4), 478-511. 
Van der Stede, W. A. (2000). The relationship between two consequences of budgetary controls: Budgetary slack creation and managerial short-term orientation. Accounting, Organizations and Society, 25(6), 609-622.

Van Vleck, R. W. (1976). Capital expenditure practices in large American corporations. The George Washington University.

Yukl, G., and Falbe, C. M. (1991). Importance of different power sources in downward and lateral relations. Journal of Applied Psychology, 76(3), 416-423. 


\begin{tabular}{|l|c|c|c|c|}
\hline \multicolumn{5}{|c|}{ Quble 1 } \\
& \multicolumn{2}{|c|}{ Country } & & \\
\hline & $\begin{array}{c}\text { Australia } \\
(\boldsymbol{n})\end{array}$ & $\begin{array}{c}\text { New Zealand } \\
(\boldsymbol{n})\end{array}$ & $\begin{array}{c}\text { Total } \\
(\boldsymbol{n})\end{array}$ & $\begin{array}{c}\text { \% of final } \\
\text { responses }\end{array}$ \\
\hline First mailing & 55 & 28 & 83 & $41.5 \%$ \\
\hline Second mailing & 36 & 11 & 47 & $23.5 \%$ \\
\hline Industry distribution & 41 & 10 & 51 & $25.5 \%$ \\
\hline Emailing distribution & 10 & 6 & 16 & $8.0 \%$ \\
\hline Telephone & 3 & 0 & 3 & $1.5 \%$ \\
\hline Total number of responses & 145 & 55 & 200 & $100 \%$ \\
\hline Total number in sample & 437 & 184 & 621 & \\
\hline \multicolumn{1}{|c|}{ Total response rate } & $33.18 \%$ & $29.89 \%$ & $\mathbf{3 2 . 2 1 \%}$ & \\
\hline $\begin{array}{l}\text { Hotels with a management } \\
\text { contract }\end{array}$ & $\mathbf{8 5}$ & $\mathbf{1 6}$ & $\mathbf{1 0 1}$ & $\mathbf{5 0 . 5 \%}$ \\
\hline
\end{tabular}




\begin{tabular}{|c|c|c|c|c|c|c|}
\hline \multicolumn{7}{|c|}{$\begin{array}{c}\text { Table } 2 \\
\text { Overview of items used to measure locus of power between hotel owner and operator }\end{array}$} \\
\hline $\begin{array}{c}\text { Power base } \\
\text { of French } \\
\text { and Raven } \\
(1959)\end{array}$ & Authors & Author's original item & Current study's adapted item ${ }^{a}$ & Mean & $\begin{array}{l}\text { Standard } \\
\text { deviation }\end{array}$ & $n$ \\
\hline \multirow{3}{*}{$\begin{array}{l}\text { Reward } \\
\text { Power }\end{array}$} & $\begin{array}{l}\text { Hinkin and } \\
\text { Schriesheim } \\
(1989)\end{array}$ & $\begin{array}{l}\text { My supervisor can increase my } \\
\text { pay level. }\end{array}$ & $\begin{array}{l}\text { RW1: Which entity is in a } \\
\text { stronger position to provide you } \\
\text { with increased pay? }\end{array}$ & 2.68 & 1.74 & 101 \\
\hline & $\begin{array}{l}\text { Hinkin and } \\
\text { Schriesheim } \\
\text { (1989) }\end{array}$ & $\begin{array}{l}\text { My supervisor can influence } \\
\text { my getting a promotion. }\end{array}$ & $\begin{array}{l}\text { RW2: Which entity is in a } \\
\text { stronger position to influence } \\
\text { your next promotion? }\end{array}$ & 2.23 & 1.45 & 100 \\
\hline & $\begin{array}{l}\text { Bachman et } \\
\text { al.(1966) }\end{array}$ & $\begin{array}{l}\text { My supervisor can give special } \\
\text { help and benefits to those who } \\
\text { cooperate with him. }\end{array}$ & $\begin{array}{l}\text { RW3: Which entity is in a } \\
\text { stronger position to give you } \\
\text { special help and benefits in } \\
\text { return for your co-operation? }\end{array}$ & 3.18 & 1.28 & 99 \\
\hline \multirow{3}{*}{$\begin{array}{l}\text { Coercive } \\
\text { power }\end{array}$} & $\begin{array}{l}\text { Bachman et } \\
\text { al. }(1966)\end{array}$ & $\begin{array}{l}\text { My supervisor can apply } \\
\text { pressure or penalize those who } \\
\text { do not cooperate [with them]. }\end{array}$ & $\begin{array}{l}\text { C1: Which entity is in a stronger } \\
\text { position to put pressure on you if } \\
\text { they perceive you to not be } \\
\text { supportive of their wishes? }\end{array}$ & 3.33 & 1.39 & 101 \\
\hline & $\begin{array}{l}\text { Hinkin and } \\
\text { Schriesheim } \\
(1989)\end{array}$ & $\begin{array}{l}\text { My supervisor can make things } \\
\text { unpleasant here. }\end{array}$ & $\begin{array}{l}\text { C2: Which entity is in a stronger } \\
\text { position to make things } \\
\text { unpleasant for you at the hotel? }\end{array}$ & 3.96 & 1.17 & 97 \\
\hline & $\begin{array}{l}\text { Hinkin and } \\
\text { Schriesheim } \\
\text { (1989) }\end{array}$ & $\begin{array}{l}\text { My supervisor can make my } \\
\text { work difficult for me. }\end{array}$ & $\begin{array}{l}\text { C3: Which entity is in a stronger } \\
\text { position to make your work } \\
\text { difficult? }\end{array}$ & 3.79 & 1.25 & 97 \\
\hline $\begin{array}{l}\text { Legitimate } \\
\text { power }\end{array}$ & $\begin{array}{l}\text { Bachman et } \\
\text { al. }(1966)\end{array}$ & $\begin{array}{l}\text { My supervisor has a legitimate } \\
\text { right, considering his position, } \\
\text { to expect that his suggestions } \\
\text { will be carried out. }\end{array}$ & $\begin{array}{l}\text { L1: Which entity is in a stronger } \\
\text { position to require that their } \\
\text { suggestions are carried out? }\end{array}$ & 3.63 & 1.28 & 101 \\
\hline
\end{tabular}




\begin{tabular}{|c|c|c|c|c|c|c|}
\hline & $\begin{array}{l}\text { Hinkin and } \\
\text { Schriesheim } \\
\text { (1989) }\end{array}$ & $\begin{array}{l}\text { My supervisor can give me the } \\
\text { feeling that I have } \\
\text { responsibilities to fulfil. }\end{array}$ & $\begin{array}{l}\text { L2: Which entity in a stronger } \\
\text { position to give you a sense of } \\
\text { importance associated with } \\
\text { fulfilling your responsibilities? }\end{array}$ & 3.62 & 1.19 & 100 \\
\hline & $\begin{array}{l}\text { Hinkin and } \\
\text { Schriesheim } \\
\text { (1989) }\end{array}$ & $\begin{array}{l}\text { My supervisor can make me } \\
\text { feel like I should satisfy my job } \\
\text { requirements. }\end{array}$ & $\begin{array}{l}\text { L3: Which entity is in a stronger } \\
\text { position to make you want to } \\
\text { achieve a high level of } \\
\text { performance? }\end{array}$ & 3.50 & 1.40 & 100 \\
\hline \multirow{3}{*}{$\begin{array}{l}\text { Expert } \\
\text { power }\end{array}$} & $\begin{array}{l}\text { Yukl and } \\
\text { Falbe (1991) }\end{array}$ & $\begin{array}{l}\text { My supervisor has the } \\
\text { experience and knowledge to } \\
\text { earn my respect, and for me to } \\
\text { defer to his/her judgment in } \\
\text { some matters. }\end{array}$ & $\begin{array}{l}\text { E1: Which entity is in a stronger } \\
\text { position to command your } \\
\text { respect? }\end{array}$ & 3.91 & 1.19 & 101 \\
\hline & $\begin{array}{l}\text { Hinkin and } \\
\text { Schriesheim } \\
(1989) \\
\end{array}$ & $\begin{array}{l}\text { My supervisor can give me } \\
\text { good technical suggestions. }\end{array}$ & $\begin{array}{l}\text { E2: Which entity is in a stronger } \\
\text { position to provide you with } \\
\text { good technical suggestions? }\end{array}$ & 2.77 & 1.26 & 101 \\
\hline & $\begin{array}{l}\text { Hinkin and } \\
\text { Schriesheim } \\
(1989)\end{array}$ & $\begin{array}{l}\text { My supervisor can provide me } \\
\text { with sound job-related advice. }\end{array}$ & $\begin{array}{l}\text { E3: Which entity is in a stronger } \\
\text { position to provide you with } \\
\text { sound job-related advice? }\end{array}$ & 2.59 & 1.30 & 100 \\
\hline \multirow{3}{*}{$\begin{array}{l}\text { Referent } \\
\text { power }\end{array}$} & $\begin{array}{l}\text { Bachman et } \\
\text { al. }(1966)\end{array}$ & $\begin{array}{l}\text { I admire my supervisor for his } \\
\text { personal qualities, and want to } \\
\text { act in a way that merits his } \\
\text { respect and admiration. }\end{array}$ & $\begin{array}{l}\text { RF1: Which entity is in a } \\
\text { stronger position to expect you } \\
\text { to act in order to win their } \\
\text { respect and admiration? }\end{array}$ & 3.80 & 0.98 & 98 \\
\hline & $\begin{array}{l}\text { Hinkin and } \\
\text { Schriesheim } \\
\text { (1989) }\end{array}$ & $\begin{array}{l}\text { My supervisor can make me } \\
\text { feel valued. }\end{array}$ & $\begin{array}{l}\text { RF2: Which entity is in a } \\
\text { stronger position to make you } \\
\text { feel valued? }\end{array}$ & 3.43 & 1.36 & 99 \\
\hline & $\begin{array}{l}\text { Hinkin and } \\
\text { Schriesheim } \\
\text { (1989) }\end{array}$ & $\begin{array}{l}\text { My supervisor can make me } \\
\text { feel personally accepted. }\end{array}$ & $\begin{array}{l}\text { RF3: Which entity is in a } \\
\text { stronger position to provide you } \\
\text { with a sense of being personally } \\
\text { accepted? }\end{array}$ & 3.46 & 1.31 & 100 \\
\hline
\end{tabular}

${ }^{a}$ These items were introduced with the wording 'In terms of your hotel owner and your hotel operating company, which entity is in a stronger position to:'. All items were measured on a Likert scale where ' 1 ' signifies high operator power and ' 7 ' signifies high owner power. 


\begin{tabular}{|l|c|c|c|c|c|c|}
\hline \multicolumn{7}{c|}{ Table 3 } \\
& $\begin{array}{c}\text { Correlation analysis of holistic power and the five sub-dimensions of power } \\
\text { polistic } \\
\text { power }\end{array}$ & $\begin{array}{c}\text { Reward } \\
\text { power }\end{array}$ & $\begin{array}{c}\text { Coercive } \\
\text { power }\end{array}$ & $\begin{array}{c}\text { Legitimate } \\
\text { power }\end{array}$ & $\begin{array}{c}\text { Expert } \\
\text { power }\end{array}$ & $\begin{array}{c}\text { Referent } \\
\text { power }\end{array}$ \\
\hline Holistic power & 1.000 & $.518^{*}$ & $.252^{*}$ & $.627^{*}$ & $.617^{*}$ & $.499^{*}$ \\
\hline Reward power & $.518^{*}$ & 1.000 & $.267^{*}$ & $.650^{*}$ & $.623^{*}$ & $.577^{*}$ \\
\hline Coercive power & $.252^{*}$ & $.267^{*}$ & 1.000 & $.442^{*}$ & $.277^{*}$ & $.335^{*}$ \\
\hline Legitimate power & $.627^{*}$ & $.650^{*}$ & $.442^{*}$ & 1.000 & $.667^{*}$ & $.746^{*}$ \\
\hline Expert power & $.617^{*}$ & $.623^{*}$ & $.277^{*}$ & $.667^{*}$ & 1.000 & $.666^{*}$ \\
\hline Referent power & $.499^{*}$ & $.577^{*}$ & $.335^{*}$ & $.746^{*}$ & $.666^{*}$ & 1.000 \\
\hline
\end{tabular}

* Significant $(p<.01)$ one-tailed.

The correlations reported in this table signify that all of the variables are highly inter-correlated. 


\begin{tabular}{|l|c|c|c|}
\hline \multicolumn{4}{|c|}{ Table 4 } \\
\hline & Relative use of NPV, IRR and payback investment appraisal techniques \\
\hline Mean & 4.67 & IRR & payback \\
\hline Std. $d e v$. & 1.62 & 4.47 & 5.78 \\
\hline$n=$ & 101 & 1.67 & 1.29 \\
\hline
\end{tabular}

All questions were posed on a 7-point Likert scale where 1 signifies low use and 7 signifies high use. 


\begin{tabular}{|c|c|c|c|c|}
\hline \multicolumn{5}{|c|}{$\begin{array}{c}\text { Table } 5 \\
\text { Questionnaire items used to measure emphasis on financial versus non-financial factors in investment appraisal }\end{array}$} \\
\hline $\begin{array}{l}\text { Categories } \\
\text { of Butler } \text { et } \\
\text { al. }(1993)\end{array}$ & Current study's measurement statements ${ }^{\mathrm{a}}$ & Mean & $\begin{array}{l}\text { Standard } \\
\text { deviation }\end{array}$ & $n$ \\
\hline \multirow{3}{*}{ Financial } & F1. The proposal is justifiable on financial grounds. & 6.15 & 0.82 & 101 \\
\hline & F2. Cash flow and profitability forecasts support the proposal's viability. & 5.96 & 1.06 & 101 \\
\hline & F3. The project's budget provides a good financial return. & 6.02 & 1.03 & 101 \\
\hline \multirow{3}{*}{$\begin{array}{l}\text { Strategic } \\
\text { factors } \\
\text { (non- } \\
\text { financial) }\end{array}$} & $\begin{array}{l}\text { S1. The proposal can be justified on the basis of gaining marketplace } \\
\text { competitive advantage. }\end{array}$ & 5.30 & 1.23 & 101 \\
\hline & $\begin{array}{l}\text { S2. The proposal is justified by a thoroughly conducted strategic analysis } \\
\text { (e.g. competitive positioning analysis, SWOT analysis). }\end{array}$ & 5.16 & 1.30 & 101 \\
\hline & S3. The project represents an opportunity to pre-empt the competition. & 4.50 & 1.44 & 101 \\
\hline \multirow{3}{*}{$\begin{array}{l}\text { Political } \\
\text { factors (non- } \\
\text { financial) }\end{array}$} & $\begin{array}{l}\text { P1. The proposal's main sponsor (i.e. the manager most closely associated } \\
\text { with the project's initiation and development) has a strong company track } \\
\text { record. }\end{array}$ & 3.90 & 1.73 & 101 \\
\hline & P2. The manager acting as the proposal's sponsor is a shrewd negotiator. & 3.43 & 1.61 & 99 \\
\hline & $\begin{array}{l}\text { P3. The manager acting as the proposal's sponsor understands internal } \\
\text { politics and uses this to their advantage in seeking company approval. }\end{array}$ & 3.50 & 1.85 & 101 \\
\hline \multirow{3}{*}{$\begin{array}{l}\text { Intuitive } \\
\text { factors } \\
\text { (non- } \\
\text { financial) }\end{array}$} & I1. The proposal appears justifiable on intuitive grounds. & 3.00 & 1.53 & 101 \\
\hline & I2. Experience suggests that the project will be successful. & 4.13 & 1.54 & 101 \\
\hline & I3.On the face of it, the proposal makes sound commercial sense. & 5.19 & 1.49 & 101 \\
\hline
\end{tabular}

${ }^{\text {a }}$ Prior to posing the questions, the questionnaire stated: 'In your hotel, to what extent do the following factors influence whether an investment proposal is given the go ahead?' All items were posed using a 7-point Likert scale: $1=$ 'not at all'; 7 = 'to a large extent' 


\section{Table 6}

Factor analytic pattern matrix for emphasis on financial versus non-financial factors in investment appraisal

\begin{tabular}{|c|c|c|c|c|}
\hline $\begin{array}{c}\text { Questionnaire } \\
\text { item }\end{array}$ & Thematic origin & $\begin{array}{c}\text { Intuitive and } \\
\text { political factor }\end{array}$ & $\begin{array}{c}\text { Financial } \\
\text { factor }\end{array}$ & $\begin{array}{c}\text { Strategic } \\
\text { factor }\end{array}$ \\
\hline I2 & Intuitive & .863 & & \\
\hline P2 & Political & .830 & & \\
\hline P3 & Political & .786 & & \\
\hline P1 & Political & .743 & & \\
\hline I1 & Intuitive & .687 & & \\
\hline I3 & Intuitive & .598 & & \\
\hline F2 & Financial & & .869 & \\
\hline F1 & Financial & & .795 & \\
\hline S1 & Financial & & & .640 \\
\hline S2 & Strategic & & & .497 \\
\hline S3 & Strategic & & & .481 \\
\hline Eigenvalue & Strategic & & 2.608 & 1.128 \\
\hline
\end{tabular}

a The 'strategic factor', 'political factor' and 'intuitive factor' are each distinct orientations concerning nonfinancial approaches to investment appraisal. The 'financial factor' gauges the extent to which financial considerations influence whether a capital expenditure proposal is supported. 
Table 7

Extent of biasing of capital budgeting cash flow forecasts measurement items: derivation and descriptive statistics

\begin{tabular}{|c|c|c|c|c|}
\hline Original item from prior literature & Current study's item & Mean & $\begin{array}{l}\text { Standard } \\
\text { deviation }\end{array}$ & $n$ \\
\hline $\begin{array}{l}\text { 'In my hotel, there is a tendency for investment } \\
\text { project sponsors (i.e. the managers most closely } \\
\text { associated with the project's initiation and } \\
\text { development) to inflate projected cash inflow } \\
\text { estimates in order to increase the likelihood of } \\
\text { the project gaining senior management support' } \\
\text { (Guilding and Lamminmaki 2007, p. 492). }\end{array}$ & $\begin{array}{l}\text { In my hotel, there is a tendency for investment } \\
\text { project sponsors (i.e. the managers most closely } \\
\text { associated with the project's initiation and } \\
\text { development) to inflate projected cash inflow } \\
\text { estimates in order to increase the likelihood of } \\
\text { the project gaining the hotel owner's support. }\end{array}$ & 2.66 & 1.49 & 100 \\
\hline $\begin{array}{l}\text { 'Revenue forecasts of capital budgeting } \\
\text { proposals (not necessarily accepted projects) } \\
\text { are typically overstated' (Pruitt and Gitman } \\
\text { 1987, p. 48). }\end{array}$ & $\begin{array}{l}\text { In my hotel, revenue forecasts of capital } \\
\text { budgeting proposals (not necessarily accepted } \\
\text { projects) are typically overstated. }\end{array}$ & 2.63 & 1.38 & 101 \\
\hline $\begin{array}{l}\text { 'Cost forecasts of capital budgeting proposals } \\
\text { (not necessarily accepted projects) are typically } \\
\text { understated' (Pruitt and Gitman 1987, p. 48). }\end{array}$ & $\begin{array}{l}\text { In my hotel, cost forecasts of capital budgeting } \\
\text { proposals (not necessarily accepted projects) are } \\
\text { typically understated. }\end{array}$ & 2.87 & 1.52 & 101 \\
\hline
\end{tabular}

${ }^{a}$ All questions in the current study were posed on a 7-point Likert scale: 1 = 'strongly disagree'; 7 = 'strongly agree'. 
Table 8

Extent of biasing of capital budgeting cash flow forecasts: frequency distribution and mean scores

\begin{tabular}{|c|c|c|c|c|c|c|c|c|c|c|}
\hline & \multicolumn{7}{|c|}{ Likert Scale } & & & \\
\hline & $\begin{array}{l}\text { Strongly } \\
\text { disagree }\end{array}$ & & & & & & $\begin{array}{c}\text { Strongly } \\
\text { agree }\end{array}$ & Mean & $\begin{array}{l}\text { Standard } \\
\text { deviation }\end{array}$ & $n$ \\
\hline Measurement item ${ }^{\mathrm{a}}$ & 1 & 2 & 3 & 4 & 5 & 6 & 7 & & & \\
\hline $\begin{array}{l}\text { In my hotel there is a tendency for } \\
\text { investment project sponsors (i.e. the } \\
\text { managers most closely associated with } \\
\text { the project's initiation and } \\
\text { development) to inflate projected cash } \\
\text { inflow estimates in order to increase the } \\
\text { likelihood of the project gaining the } \\
\text { hotel owner's support. }\end{array}$ & $23 \%$ & $33 \%$ & $20 \%$ & $11 \%$ & $6 \%$ & $6 \%$ & $1 \%$ & 2.66 & 1.49 & 101 \\
\hline $\begin{array}{l}\text { In my hotel, revenue forecasts in capital } \\
\text { budgeting proposals (not necessarily } \\
\begin{array}{l}\text { accepted projects) are typically } \\
\text { overstated. }\end{array}\end{array}$ & $20.8 \%$ & $33.7 \%$ & $23.8 \%$ & $9.9 \%$ & $7.9 \%$ & $3.0 \%$ & $1.0 \%$ & 2.63 & 1.38 & 101 \\
\hline $\begin{array}{l}\text { In my hotel, cost forecasts in capital } \\
\text { budgeting proposals (not necessarily } \\
\text { accepted projects) are typically } \\
\text { understated. }\end{array}$ & $17.8 \%$ & $32.7 \%$ & $18.8 \%$ & $14.9 \%$ & $8.9 \%$ & $5.0 \%$ & $2.0 \%$ & 2.87 & 1.52 & 101 \\
\hline
\end{tabular}

${ }^{a}$ All questions in the current study were posed on a 7-point Likert scale: 1 = 'strongly disagree'; 7 = 'strongly agree'. 


\begin{tabular}{|l|c|c|c|c|c|c|c|}
\hline \multicolumn{9}{|c|}{ Table 9 } \\
& $\begin{array}{c}\text { CBCFF } \\
\text { _biasing }\end{array}$ & Power_locus & $\begin{array}{c}\text { Emphasis_ } \\
\text { payback }\end{array}$ & $\begin{array}{c}\text { Adequacy_ } \\
\text { FF\&E }\end{array}$ & $\begin{array}{c}\text { Challenge_ } \\
\text { FF\&E_release }\end{array}$ & $\begin{array}{c}\text { Contract_ } \\
\text { length }\end{array}$ & $\begin{array}{c}\text { Financial_ } \\
\text { Emphasis }\end{array}$ \\
\hline CBCFF_biasing & 1.000 & -.204 & .224 & -.270 & .238 & -.269 & -.349 \\
\hline Power_locus & $-.204^{*}$ & 1.000 & -.080 & .063 & -.178 & -.021 & .077 \\
\hline Emphasis_payback & $.224^{*}$ & -.080 & 1.000 & .027 & .074 & -.128 & .157 \\
\hline Adequacy_FF\&E & $-.270^{*}$ & .063 & .027 & 1.000 & -.161 & .096 & -.028 \\
\hline $\begin{array}{l}\text { Challenge_FF\&E_ } \\
\text { release }\end{array}$ & $.238^{*}$ & -.178 & .074 & -.161 & 1.000 & -.140 & .154 \\
\hline Contract_length & $-.269^{*}$ & -.021 & -.128 & .096 & -.140 & 1.000 & .035 \\
\hline Financial_emphasis &.$- .349^{*}$ & .077 & .157 & -.028 & .154 & .035 & 1.000 \\
\hline
\end{tabular}

$*$ Significant $(p<.05)$ one-tailed.

CBCFF_biasing $=$ Extent of biasing of capital budgeting cash flow forecasts.

Power_locus: Locus of power between hotel owner and operator

Emphasis_payback: Emphasis attached to the payback investment appraisal method

Adequacy_FF\&E: Adequacy of funds allocated to the FF\&E reserve account

Challenge_FF\&E_release: Challenge in accessing FF\&E reserve account funds

Contract_length: Remaining length of management contract

Financial_emphasis: Emphasis on financial versus non-financial factors in investment appraisal 
Table 10

Results from regression analysis

Regression equation

$Y=\beta_{0}+\beta_{1}$ POWER_LOCUS $+\beta_{2}$ EMPHASIS_PAYBACK $+\beta_{3}$ ADEQUACY_FF\&E $+\beta_{4}$ CHALLENGE_FF\&E_RELEASE + $\beta_{5}$ CONTRACT_LENGTH $+\beta_{6}$ FINANCIAL_EMPHASIS $+e$

\begin{tabular}{|l|l|l|l|l|l|l|l|l|l|l|}
\hline & $\beta_{0}$ & $\beta_{1}$ & $\beta_{2}$ & $\beta_{3}$ & $\beta_{4}$ & $\beta_{5}$ & $\beta_{6}$ & Adj. $R^{2}$ & $F(d f=6,65)$ & $p$ \\
\hline Standardised Coef. & 0 & $-.105 \dagger$ & $.250 \dagger^{*}$ & $-.231 \dagger^{* *}$ & $.203 \dagger^{* *}$ & $-.174 \dagger^{* *}$ & $-.412 \ddagger^{*}$ & $32.2 \%$ & 6.614 & .000 \\
\hline (t-stat.) & 7.238 & $(-1.045)$ & $(2.484)$ & $(-2.325)$ & $(1.970)$ & $(-1.740)$ & $(-4.074)$ & & & \\
\hline
\end{tabular}

$\dagger$ One-tailed test

$\$$ Two-tailed test

$* p<0.01$

$* * p<0.05$

Power_locus: Locus of power between hotel owner and operator

Emphasis_payback: Emphasis attached to the payback investment appraisal method

Adequacy_FF\&E: Adequacy of funds allocated to the FF\&E reserve account

Challenge_FF\&E_release: Challenge in accessing FF\&E reserve account funds

Contract length: Remaining length of management contract

Financial_emphasis: Emphasis on financial versus non-financial factors in investment appraisal 


\footnotetext{
${ }^{1}$ Senior hotel personnel interview observations made by the research team over several years of research enquiry, suggest it is commonplace for a capital expenditure proposal submitted by a hotel operator to a hotel owner to be accompanied by a quantitatively based justification of the proposal. Further, in hotels where an owner emphasises discounted cash flow analysis in investment appraisal, the operator tends to initiate a discounted cash flow analysis in submitted proposals. This provides operators with scope to influence the discount rate used in an owner's appraisal of a capital expenditure proposal's merit.

2 This hypothesised relationship may be somewhat negated in those situations where both the owner and operator have an expectation that the contract will be renewed. It is notable, however, that many management contracts specify a maximum number of renewals (typically one or two) between an owner and an operator, with respect to a particular hotel (Bader and Lababedi 2007).

An investigation has been conducted into the sensitivity of the results with respect to which measure of FF\&E reserve adequacy is taken. It was found that no significant changes in the findings result if the alternative measure were adopted.

${ }^{4}$ Additional justification for the removal of the three items associated with 'strategic factors' is that such factors are sometimes viewed as a hybrid of both financial and nonfinancial factors (Fleisher 2007).

${ }^{5}$ Means and standard deviations for each of the three items as well as the factor developed are discussed in further detail in the results section.

6 Table 10 reports the results of a regression analysis where missing cases were excluded listwise, signifying that the analysis was based on 71 cases (i.e. 30 cases had one or more missing values). A missing values analysis revealed that missing data were missing completely at random (MCAR) (Little's MCAR test: Chi-Square $=32.204, d f=32$, $p=457)$. Using the 'Missing Values Analysis' function in SPSS, an Estimation Maximisation (EM) dataset was derived and the multiple regression re-run based on the EM dataset. Consistent with the model reported in Table 10, the results of this EM multiple regression model were statistically significant $(\mathrm{F}=6.626, p<.000, d f=6,94)$. Likewise, the results of hypothesis testing remained largely the same. Statistically significant support for hypotheses 3 and 5 increased from $p<.05$ to $p<.01$, while support for hypothesis 2 decreased from $p<.01$ to $p<.05$. Given that the missing data were MCAR, there is no disadvantage in reporting the results of the listwise model in the hypothesis testing results noted in the main body of the paper.

${ }^{7}$ In order to test for the robustness of this finding, the five distinct dimensions of power were each substituted for the holistic power measure in five further iterations of the multiple regression model. In each of these five further multiple regression models, the variables reported as significant in Table 10 did not change. This signifies that our findings do not appear to be sensitive to the particular power measure used in the regression model formulated to test the study's hypotheses.
} 